\title{
7. ve 8. Sınıf Öğrencilerinin Sınav Kaygısı ve Benlik Saygısı Arasındaki İlişkinin İncelenmesi
}

\section{The Analysis of Relationship Between Test Anxiety and Self-Esteem in the Case of 7th and 8th Grade Students}

\author{
Aygen Çakmak \\ Kırıkkale Üniversitesi Sağlık Bilimleri Fakültesi Çocuk Gelişimi Bölümü \\ e-posta:ayalp71@gmail.com \\ Hande Sahin \\ Kırıkkale Üniversitesi Sağlık Bilimleri Fakültesi Sosyal Hizmet Bölümü \\ e-posta:hande_k1979@yahoo.com \\ Ezgi Akıncı Demirbaş \\ Kırıkkale Üniversitesi Sağlık Bilimleri Fakültesi Çocuk Gelişimi Bölümü \\ e-posta:akinciezgi87@gmail.com
}

\begin{abstract}
Özet
$\mathrm{Bu}$ araştırmanın amacı, ortaokul 7. ve 8. sınıfa devam eden öğrencilerin sınav kaygısı ve benlik saygısı arasındaki ilişkinin incelenmesi ve bazı değişkenlerin sınav kaygısı ve benlik saygısı puanlarında farklılık oluşturup oluşturmadığının belirlenmesidir. Araştırma 2016-2017 eğitim-öğretim yılında Kırıkkale ilinde rastgele örnekleme yöntemi ile seçilen ortaokullarda yedinci ve sekizinci sınıf $(n=334)$ ögrencileri ile yürütülmüştür. Araştırmanın verileri, Sınav Kaygı Envanteri, Rosenberg Benlik Saygısı Ölçeği, Kişisel Bilgi Formu ile toplanmış, verilerin analizinde t-testi, Varyans analizi ve korelasyon analizi kullanılmıştır. Araştırma sonucunda; kız öğrencilerin erkeklere göre sınav kaygılarının anlamlı derecede yüksek olduğu, sınav kaygısı ile benlik saygısı arasında negatif yönde anlamlı bir ilişki bulunduğu belirlenmiştir. Ancak cinsiyet, sınıf, anne-baba eğitim durumu değişkenlerinin benlik saygısı puan ortalamalarında anlamlı bir farklılık oluşturmadığı saptanmıştır.
\end{abstract}

Anahtar kelimeler: Sınav kaygısı, benlik saygısı, ortaokul öğrencileri.

\begin{abstract}
The purpose of this study is to examine the relationship between test anxiety and self-esteem in the case of 7 th and 8th grade students and to establish whether certain variables bring about a difference in the scores of test anxiety and self-esteem. The present study was conducted with the seventh and eighth grade students $(n=334)$ who were selected through random sampling in the province of Kirkkale during the Academic Year 2016-2017. Data pertaining to the study was collected through Test Anxiety Inventory, Rosenberg Self-Esteem Scale and Personal Information Forms and analyzed by t-test, Variance analysis and Correlation analysis . As a result of the study, it was established that female students had significantly higher levels of test anxiety than male students and that there was a negatively significant relationship between test anxiety and self-esteem. That being said, however, no statistically significant difference was established in the average self-esteem scores in terms of gender, grade and parental educational status variables.
\end{abstract}

Keywords: Test anxiety, self-esteem, secondary school students.

\section{GíRiş}

Sınavlar öğrencilerin hayatlarının şekillenmesindeki önemli süreçler olup, bu durum onların kaygıllarını artırabilmektedir. Sınavların öğrencilerde oluşturduğu kaygı, öğrencilerin derslere karşı tutumunu ve başarısını olumsuz yönde etkileyebilmektedir (Dündar ve ark., 2008). Spielberger'e (1972) göre sinav kaygısı; formal bir sınav veya değerlendirme durumunda yaşanan, bireyin gerçek performansını ortaya koymasını engelleyen bilişsel, duyuşsal, davranışsal özellikleri olan, bireyde gerginlik yaratan hoş olmayan bir duygu durumudur (Spielberger, 1972). Bu noktada sınav kaygısı, özel bir kaygı çeşidi olup bireyin değerlendirilmesi söz konusu olduğunda hissedilen korkuyla karışık bir tedirginlik duygusudur. Sınav kaygısı birçok ülkede ilkokuldan sonraki eğitim ve öğretime hazırlanmada yoğun olarak yaşanan ve beraberinde birçok olumsuzluğu getiren güncel bir konudur (Erözkan, 2004).

Benlik, bireyin varlı̆ğın ve deneyimlerinin bilinçli olarak algılanan bütün yönlerini kapsamaktadır (İnanç ve Yerlikaya,2008). Benlik saygısı ise, kişinin kendini değerlendirmesi sonucu ulaştığı benlik kavramını kabul etmesinden doğan bir beğeni durumudur. Kişi kendinde bazı eksiklikler bulması yönüyle kendini eleş̧irdiği gibi kendini eksiksiz de görebilir. Benlik saygısı bireyin kendini olduğu gibi, ne çok aşağı ne de çok üstün görmeden değerlendirip, sonuçtan memnun olması durumudur (Yörükoğlu, 2000). 
Benlik saygısı yüksek olan öğrenciler gerek sosyal ilişkilerinde gerekse okul çalışmalarında daha girişimci, daha güvenli, daha ataktırlar. Yeni şeyleri öğrenmeye daha meraklıdırlar ve yeni durumlarla karşılaşmaktan korkmazlar. Benlik saygısı düzeyleri düşük öğrenciler ise bunların aksine kendilerine daha az güven duyar ve onlardan istenilenleri başaramayacakları kaygısını daha yoğun yaşarlar. Bu nedenle, başarısızlık sonrası oluşacak doğal mahcubiyet duygusunu yaşamamak için bu gibi riskli durumlardan kendilerini sürekli olarak uzak tutmaya çalışırlar (Pişkin,2002).

Bilindiği üzere ülkemizde 8. sınıf öğrencileri TEOG sınavı ile kendilerine uygun olan liseleri seçmektedirler. Ortaöğretime geçişte bu sınavın önemi 8. sinıflar için oldukça büyüktür. Ancak öğrenciler bu dönemde hem ergenlik sorunlarıyla hem de okulun, ailenin sınav beklentileri ve yüksek baskısı altında kalmaktadırlar. Bir yandan okul ve kurslarla yoğun bir çalışma temposu ile; diğer yandan sınav kaygısı ile baş etmek durumundadırlar (Aydın ve Bulgan, 2017; Gülbahçe ve Kartol, 2014). Nitekim yapılan literatür taramasında sınav kaygısı ve benlik saygısı arasındaki ilişkiyi ortaya koyan çalışmalara rastlanmasına rağmen (Ünal,2006; Başoğlu 2007; Kabalcı 2008; Erözkan 2009) ortaöğretim 7. ve 8.sınıf öğrencilerinin sınav kaygısı ve benlik saygıları arasındaki ilişkiyi inceleyen bir araştırmaya rastlanmamıştır. Özellikle 8. sınıf öğrencilerinin TEOG sınavına girecekleri düşünüldüğünde, cinsiyet, sınıf, anne-baba eğitim durumunun sınav kaygısı ve benlik saygısı puanlarında farklılık oluşturup oluşturmadığının belirlenmesi, sınav kaygısı ve benlik saygısı arasındaki ilişkinin incelenmesinin literatüre katkı sağlayacağı düşünülmektedir.

\section{YÖNTEM}

Araştırma Kırıkkale il merkezinde yer alan ve rastgele örnekleme yöntemiyle belirlenen ortaokullardan 7. ve 8. sınıfa devam eden öğrencilerin cinsiyet, sınıf, anne-baba eğitim durumunun sınav kaygısı ve benlik saygısı puanlarında farklılık oluşturup oluşturmadığının belirlenmesi, sınav kaygısı ve benlik saygısı arasındaki ilişkinin incelenmesi amacıyla planlanmıştır. Bu araştırmada, genel tarama modeli türlerinden birisi olan ilişkisel tarama türü kullanılmıştır. Genel tarama modelleri, geçmişte ya da içinde bulunduğumuz anda var olan bir durumun, olduğu gibi yansız ve tarafsız olarak, betimlenmesini amaçlayan araştırma modelidir. Bu modelin en dikkat çeken özelliği ise, var olanı değiştirmeden olduğu gibi gözlemleyebilmektir. İlişkisel tarama modelinde ise, birden fazla değişken arasındaki birlikte değişim olup olmadığını, eğer değişim var ise değişimin derecesini belirlemeyi amaçlayan araştırma modellerinden birisidir (Karasar, 2008).

\section{Çalışma Grubu}

Araştırma, Kırıkkale il merkezinde küme örnekleme yoluyla tesadüfi olarak belirlenen farklı sosyoekonomik düzeyleri temsil eden 8 ortaokulda yedinci ve sekizinci sınıf 334 öğrenci üzerinde yürütülmüş̧ür. Bu araştırmanın çalışma grubunda yer alan öğrencilerin 163 'ü (\% 48.8) kız ve 171 'i (\% 51.2) erkek öğrencidir. Öğrencilerin 167’si (\%50. 0) yedinci sınıf, 167’si (\% 50. 0) sekizinci sınıftır.

\section{Veri Toplama Araçları}

Araştırmada veri toplamak amacıyla "Kişisel Bilgi Formu", "Sınav Kaygısı Envanteri" ve "Rosenberg Benlik Saygısı Ölçeği” kullanılmıştır.

Kişisel Bilgi Formu: Araştırmacılar tarafından hazırlanan form araştırmaya katılan öğrencilerin demografik özelliklerin (cinsiyet, sınıf, anne eğitim durumu, baba eğitim durumu vb. ) belirlenmesinde kullanılmıştır.

Sinav Kaygısı Envanteri: Spielberger (1972) tarafindan geliştirilen, Öner (1990) tarafindan Türkçeye çevrilen Sınav Kaygısı Envanteri 20 sorudan oluşmaktadır. Sinav Kaygısı Envanteri, "Kuruntu Kaygısı" ve "Duyuşsal Kaygı" olmak üzere iki alt testten oluşmaktadır. Seçeneklere verilen yanıtların ağırlıkları 1 ile 4 puan arasında değişmektedir. Tüm testten alınacak en düşük puan 20 , en yüksek puan ise 80 'dir. Bu araştırmada tüm test puanları kullanılmıştır. Bu araştırmada çalışma grubundan alınan puanlara göre tüm test için Cronbach Alfa katsayıs1 .87 olarak bulunmuştur.

Rosenberg Benlik Saygısı Ölçeği: 7 ve 8. sınıf öğrencilerinin benlik saygısı düzeylerinin belirlenmesi için Morris Rosenberg tarafindan 1963 yılında geliştirilen A.B.D'de geçerlilik ve güvenirlik çalışmaları Rosenberg tarafindan 1965 yılında yapıldıktan sonra birçok araştırmada araç olarak kullanılmış Benlik Saygısı Ölçeği kullanılmıştır. Rosenberg Benlik Saygısı Ölçeği’nin Türkiye'ye uyarlama çalışmaları, Çuhadaroğlu (1986) tarafindan yapılmıştır. Tüm test için Cronbach Alpha değeri 0.76 olarak bulunmuştur. Test - tekrar test güvenirlilik katsayısı ise 0.71 olarak saptanmıştır. Bu araştırmada çalışma grubundan alınan puanlara göre tüm test için Cronbach Alfa katsayıs1 .73 olarak bulunmuştur. 
Rosenberg, benlik saygısı kavramında kişinin kendisini değerlendirmesinin önemi üzerinde durmaktadır. Ölçekteki sorular daha çok bu temaya yöneliktir. Rosenberg Benlik Saygısı Ölçeği, çoktan seçmeli sorulardan yapılanmış on iki alt kategoriden oluşmaktadır. Bunlar; Benlik Saygısı, Kendilik Kavramının Sürekliliğ̈i, İnsanlara Güvenme, Eleştiriye Duyarlılık, Depresif Duygulanım, Hayalperestlik, Psikosomatik Belirtiler, Kişiler arası Tehdit Hissetme, Tartı̧̧malara Katılabilme, Ana-baba İlgisi, Babayla İlişki, Psişik İzolasyon'dur. Bu araştırmada, ölçeğin alt ölçekleri arasından Benlik Saygısı alt ölçeği kullanılacaktır. Benlik Saygısı Alt Ölçeği'nde on madde yer almaktadır. Ölçeğin kendi içindeki değerlendirme sistemine göre denekler 0 ile 6 arasında puan almaktadırlar. Sayısal ölçümlerle yapılan karşılaştırmalarda benlik saygısı yüksek (0-1) puan, orta (2-4) puan, düşük (5-6) puan olarak değerlendirilmektedir. Dolayısıyla Benlik Saygısı Ölçeği’nden düşük puan alan bireylerin yüksek düzeyde benlik saygısına sahip oldukları, yüksek puan alanların ise düşük düzeyde benlik saygısına sahip oldukları söylenebilir.

\section{Veri Toplama İsslemi}

Kırıkkale İl Milli Eğitim Müdürlüğü ile gerekli yazışmalar yapılarak 14.12.2016 tarih ve E.14123095 sayılı yazıyla araştırmanın yapılabilmesi için izin alınmıştır. Araştırma verileri Aralık 2016 - Ocak 2017 tarihleri arasında öğrencilerle yapılan yüz yüze görüşmeler sonucu araştırmacılar tarafindan toplanmıştır. Anket formu öğrencilere verilmeden önce araştırmanın amacı hakkında bilgilendirme yapılmış, gönüllü olanların araştırmaya dahil edilmesi sağlanmıştır.

\section{Verilerin Analizi}

Bu çalışmada elde edilen veriler SPSS 16.0 paket programı ile değerlendirilmiştir. Verilerin öncelikle normal dağılıp dağılmadığını belirlemek için normallik testi uygulanmıştır. Sınav Kaygısı Envanteri ile Rosenberg Benlik Saygısı Ölçeği "Benlik Saygısı" alt boyutu puanlarına ait normallik testi sonuçlarının normal dağılım göstermediği ancak örneklem büyük $(\mathrm{n}=334)$ ve çarpıklık değerleri $+1,-1$ aralığında olduğu için puanların normal dağılımdan önemli bir sapma göstermediği şeklinde yorumlanmıştır.

Normallik testi sonucunda, gruplar arasında farklılık incelenirken cinsiyet ve sınıf değişkenin alınan puanlarda farklıı̆ğa neden olup olmadığını anlamak için t-testi, anne-baba eğitim durumu değişkeninde ise Tek Yönlü Varyans Analizi kullanılmıştır. Öğrencilerin sınav kaygısı ve benlik saygısı puanları arasında anlamlı bir ilişki olup olmadığını belirlemek üzere de, iki sürekli değişken arasındaki doğrusal ilişkinin derecesini saptamak için Korelasyon katsayısı hesaplanmıştır.

\section{BULGULAR}

Çalışmaya katılan öğrencilerin sınav kaygısı puanlarının cinsiyet ve sınıf değişkenlerine göre karşılaştırılmasına ait t-testi sonuçları Tablo 1'de sunulmuştur.

Tablo 1.

Öğrencilerin sınav kaygısı puanlarının cinsiyet ve sınıf değişkenlerine göre karşılaştırılması

\begin{tabular}{|c|c|c|c|c|c|c|c|}
\hline Ölçek & Cinsiyet & $\mathrm{n}$ & $\overline{\mathrm{X}}$ & ss & $\mathrm{sd}$ & $\mathrm{t}$ & $\mathrm{p}$ \\
\hline \multirow{5}{*}{ Sinav Kaygis1 } & Kiz & 163 & 41.80 & 10.97 & 332 & 1.942 & $.045 *$ \\
\hline & Erkek & 171 & 39.66 & 9.48 & & & \\
\hline & Sinıf & & & & & & \\
\hline & 7.sinif & 167 & 40.40 & 10.07 & 332 & -.542 & .588 \\
\hline & 8.sinif & 167 & 42.08 & 10.50 & & & \\
\hline
\end{tabular}

*p<.05

Tablo 1'de görüldüğü gibi; kız öğrencilerin sınav kaygısı puan ortalamalarının ( $\bar{X}=41.80)$, erkek öğrencilerin puan ortalamalarından $(\bar{X}=39.66)$ daha yüksek olduğu, öğrencilerin sınav kaygısı puanlarının cinsiyete göre istatistiksel olarak anlamlı farkl1lık gösterdiği görülmektedir $\left(\mathrm{t}_{(332)}=1.942, \mathrm{p}<.05\right)$.

Sınıf değişkenine göre; 8.sınıf öğrencilerinin sınav kaygısı puan ortalamalarının ( $\bar{X}=42.08)$ 7.sınıfa devam eden öğrencilerden $(\bar{X}=40.40)$ daha yüksek olduğu ancak yapılan t- testi sonucunda; öğrencilerin devam ettikleri sınıfin sınav kaygısı puanlarında göre istatistiksel olarak anlamlı bir farklılığa neden olmadığı belirlenmiştir $(\mathrm{p}>.05)$.

Öğrencilerin benlik saygısı puanlarının cinsiyet ve sınıf değiş̧kenlerine göre karşılaştırılmasına ait t-testi sonuçları Tablo2'de sunulmuştur. 
Tablo 2

Öğrencilerin benlik saygısı puanlarının cinsiyet ve sınıf değişkenlerine göre karşılaşstırılması

\begin{tabular}{llllrrrr}
\hline Ölçek & Cinsiyet & $\mathrm{n}$ & $\overline{\mathrm{X}}$ & ss & $\mathrm{sd}$ & $\mathrm{t}$ & $\mathrm{p}$ \\
\hline Benlik Saygıs1 & Kız & 163 & 1.19 & 0.78 & 332 & -.466 & .642 \\
\hline & Erkek & 171 & 1.23 & 0.68 & & & \\
\hline & Sinıf & & & & & & \\
\hline & $7 . \sin 1 \mathrm{f}$ & 167 & 1.23 & 0.71 & 332 & .533 & .594 \\
\hline & $8 . \sin 1 \mathrm{f}$ & 167 & 1.19 & 0.76 & & & \\
\hline
\end{tabular}

$* \mathrm{p}<.05$

Tablo 2'de öğrencilerin benlik saygısı puanlarının cinsiyet ve sınıf değişkenine göre karşılaştırılmasına ilişkin sonuçlar yer almaktadır. Rosenberg Benlik Saygısı Ölçeği’nin puanlama özelliğinden yüksek puanlar düşük benlik saygısını, düşük puanlar ise yüksek benlik saygısını göstermektedir. Araştırmaya katılan kız öğrencilerin erkek öğrencilere, 8. sınıf öğrencilerinin 7.sınıf öğrencilerine göre benlik saygısı düzeylerinin daha yüksek olduğu ancak yapılan analiz sonucunda cinsiyet $\left(\mathrm{t}_{(332)}=-.466, \mathrm{p}=0.642\right)$ ve $\sin 1 \mathrm{f}\left(\mathrm{t}_{(332)}=.533, \mathrm{p}=0.594\right)$ değişkenlerinin benlik saygısı puanlarında göre istatistiksel olarak anlamlı bir farklılık oluşturmadığı belirlenmiştir.

Öğrencilerin sınav kaygısı puanlarının anne-baba eğitim durumu değişkenine göre farklılaşıp farklılaşmadığını belirlemek üzere yapılan tek yönlü varyans analizi sonuçları Tablo3'de sunulmuştur.

Tablo 3

Sinav kaygısı puanlarının anne-baba eğitim durumu değişkenine göre Anova sonuçları

\begin{tabular}{|c|c|c|c|c|c|c|c|c|c|c|}
\hline Puan & $\begin{array}{l}\text { Anne Eğitim } \\
\text { Durumu }\end{array}$ & $\mathrm{N}$ & $\bar{X}$ & ss & $\begin{array}{l}\text { Varyansın } \\
\text { Kaynağı }\end{array}$ & $\mathrm{KO}$ & sd & KT & $\mathrm{F}$ & $\mathrm{p}$ \\
\hline \multirow{13}{*}{ Sinav Kaygisı } & Okur-yazar değil & 12 & 39.13 & 0.91 & G.Aras1 & 119.35 & 4 & 477.42 & 1.13 & .342 \\
\hline & İlkokul & 86 & 41.47 & 2.66 & G. İçi & 105.44 & 329 & 34723.82 & & \\
\hline & Ortaokul & 99 & 41.17 & 1.00 & Toplam & & 333 & 35201.24 & & \\
\hline & Lise & 116 & 41.00 & 4.23 & & & & & & \\
\hline & Üniversite & 21 & 42.05 & 1.07 & & & & & & \\
\hline & Toplam & 334 & 40.76 & 0.56 & & & & & & \\
\hline & $\begin{array}{l}\text { Baba Eğitim } \\
\text { Durumu }\end{array}$ & & & & & & & & & \\
\hline & Okur-yazar değil & 7 & 41.00 & 6.70 & G.Aras1 & 87.09 & 4 & 348.36 & 0.82 & .512 \\
\hline & İlkokul & 35 & 43.14 & 2.03 & G. İçi & 105.93 & 329 & 34852.87 & & \\
\hline & Ortaokul & 78 & 40.02 & 1.29 & Toplam & & 333 & 35201.24 & & \\
\hline & Lise & 146 & 41.01 & 0.80 & & & & & & \\
\hline & Üniversite & 68 & 39.60 & 1.05 & & & & & & \\
\hline & Toplam & 334 & 40.70 & 0.56 & & & & & & \\
\hline
\end{tabular}

$* \mathrm{p}<.05$

Tablo 3 incelendiğinde, üniversite mezunu anneye sahip olan öğrencilerin sınav kaygısı $(\bar{X}=42.05)$ puan ortalamalarının, okur-yazar olmayan anneye sahip öğrencilerin $(\overline{\mathrm{X}}=39.13)$ ortalamalarından daha yüksek olduğu görülmektedir. Üniversite mezunu babaya sahip olan öğrencilerin sınav kaygısı puan ortalamaları ise diğer grupta yer alan öğrencilerin puan ortalamalarından daha düşüktür. Ancak yapılan analiz sonucunda sinav kaygısı puan ortalamaları arasında anne eğitim $\left[\mathrm{F}_{(4-329)}=1.13, \mathrm{p}>.05\right]$ ve baba eğitim durumuna $\left[\mathrm{F}_{(4-329)}=0.82\right.$, $\mathrm{p}>$.05] göre gözlenen fark göre istatistiksel olarak anlamlı bulunmamıştır.

Benlik saygısı puanlarının anne-baba eğitim durumu değişkenine göre farklılaşıp farklılaşmadığını belirlemek üzere yapılan tek yönlü varyans analizi sonuçları Tablo 4'te sunulmuştur.

Tablo 4

Benlik saygısı puanlarının anne-baba eğitim durumu değişkenine göre Anova sonuçları

\begin{tabular}{|c|c|c|c|c|c|c|c|c|c|c|}
\hline Puan & $\begin{array}{l}\text { Anne Eğitim } \\
\text { Durumu }\end{array}$ & $\mathrm{N}$ & $\overline{\mathrm{X}}$ & ss & $\begin{array}{l}\text { Varyansın } \\
\text { Kaynağı }\end{array}$ & $\mathrm{KO}$ & $\mathrm{Sd}$ & KT & $\mathrm{F}$ & $\mathrm{p}$ \\
\hline & Okur-yazar değil & 12 & 1.14 & 0.22 & G.Aras1 & 0.59 & 4 & 2.38 & 1.10 & .355 \\
\hline & İlkokul & 86 & 1.25 & 0.08 & G. İçi & 0.54 & 329 & 173.29 & & \\
\hline & Ortaokul & 99 & 1.25 & 0.07 & Toplam & & 333 & 175.67 & & \\
\hline & Lise & 116 & 1.12 & 0.06 & & & & & & \\
\hline & Üniversite & 21 & 1.44 & 0.19 & & & & & & \\
\hline
\end{tabular}




\begin{tabular}{|c|c|c|c|c|c|c|c|c|c|c|}
\hline \multirow[t]{8}{*}{ Benlik Saygısı } & Toplam & 334 & 1.21 & \multicolumn{7}{|l|}{0.04} \\
\hline & $\begin{array}{l}\text { Baba Eğitim } \\
\text { Durumu }\end{array}$ & & & & & & & & & \\
\hline & Okur-yazar değil & 7 & 1.27 & 0.36 & G.Aras1 & 0.09 & 4 & 0.39 & 0.18 & .948 \\
\hline & İlkokul & 35 & 1.22 & 0.14 & G. İçi & 0.54 & 329 & 175.27 & & \\
\hline & Ortaokul & 78 & 1.15 & 0.08 & Toplam & & 333 & 175.67 & & \\
\hline & Lise & 146 & 1.23 & 0.05 & & & & & & \\
\hline & Üniversite & 68 & 1.22 & 0.10 & & & & & & \\
\hline & Toplam & 334 & 1.21 & 0.04 & & & & & & \\
\hline
\end{tabular}

\section{$* \mathrm{p}<.05$}

Tablo 4'de öğrencilerin benlik saygısı puanlarının anne-baba eğitim durumu değişkenine göre farklılaşıp farklılaşmadığını belirlemek üzere yapılan varyans analizi (Anova) sonuçları görülmektedir. Rosenberg Benlik Saygısı Ölçeği’nin puanlama özelliğinden yüksek puanlar düşük benlik saygısını, düşük puanlar ise yüksek benlik saygısını göstermektedir. Üniversite mezunu anneye sahip öğrencilerle $(\bar{X}=1.44)$, okur -yazar olmayan babaya sahip olan öğrencilerin $(\bar{X}=1.27)$ düşük benlik saygısı düzeyine sahip oldukları belirlenmiştir. Ancak analiz sonucunda benlik saygısı puan ortalamaları arasında anne eğitim $\left[\mathrm{F}_{(4-329)}=1.10\right.$, $\mathrm{p}>$.05] ve baba eğitim durumunun $\left[\mathrm{F}_{(4-329)}=0.18, \mathrm{p}>.05\right]$ istatistiksel olarak anlamlı bir farklılık oluşturmadığ saptanmıştır.

Öğrencilerin sınav kaygısı-benlik saygısı arasındaki korelasyon Tablo 5'de sunulmuştur.

Tablo 5.

Öğrencilerin sınav kaygısı-benlik saygısı arasındaki korelasyon

\begin{tabular}{llcc} 
& $\mathrm{N}$ & $\mathrm{r}$ & $\mathrm{P}$ \\
\hline Sinav Kaygisı & \multirow{2}{*}{334} & -.422 & $.000^{*}$ \\
Benlik Sayg1s1 & & & \\
\hline
\end{tabular}

$$
* \mathrm{p}<.05
$$

Tablo 5'e bakıldığında, sınav kaygısı ile benlik saygısı puanları arasındaki ilişkiyi belirlemek üzere yapılan analiz sonucunda puanlar arasında istatistiksel açıdan orta düzeyde negatif yönde anlamlı bir ilişki saptanmıştır $(\mathrm{r}=-.422$; $\mathrm{p}<.05)$. Buna göre öğrencilerin sınav kaygısı puanları yükseldikçe benlik kavramı puanlarının düştüğü söylenebilir.

\section{SONUÇ ve TARTIŞMA}

Çalışmadan elde edilen sonuçlar incelendiğinde, kız öğrencilerin sınav kaygısı puan ortalamalarının erkek öğrencilerden daha yüksek olduğu, öğrencilerin sınav kaygısı puanlarının cinsiyete göre anlamlı farklılık gösterdiği belirlenmiştir. Sınav kaygısının cinsiyete göre incelendiği çeşitli (Bacanlı ve Sürücü, 2006; Başoğlu, 2007; Brown, 2002; Cassady ve Johnson, 2002; Di Maria ve Di Nuovo, 1990; Duman, 2008; Kayapınar 2006, Rasor ve Rason, 1998; Uysal, 2007, Ünal, 2006, Zeidner ve Scheleyer, 1999) araştırmaların sonuçları da kız öğrencilerin sınav kaygılarının erkeklerinkinden daha yüksek olduğu yönündedir. Erkek çocukları akademik alanda başarılı olamadıkları takdirde toplumsal statüsü düşük olsa da bir şekilde kendilerine uygun bir meslek edinebilmektedirler. Erkek öğrencilerin de böyle bir imkanlarının bulunması, bu alana yönelerek akademik başarıyı daha hafife almalarına neden olmuş olabilir. Kız çocuklarının annelerinin ekonomik alanda özgür olamadıkları için yaşadıkları sıkıntıları gözlemleyen kız çocuklarının aynı sıkıntıları yaşamak istememesi, bu nedenle akademik alanda kendilerini geliştirmeye çalışmaları kız ve erkekler arasındaki farklılık olarak düşünülebilir. Sınıf değişkenine göre; 8.sınıf öğrencilerinin sınav kaygıları 7.sınıfa devam eden öğrencilerden daha yüksektir. Çelebi (2007), ilköğretim II. kademe öğrencilerinin Orta Öğretim Kurumları Sınavı (OKS)’nı (şu anda TEOG Sınavı) kazanamama korkusu ile sınıf düzeyleri açısından anlamlı farkın 8. sınıflardan kaynaklandığını belirlemiştir. Ancak yapılan t- testi sonucunda; öğrencilerin devam ettikleri sınıfın sınav kaygısı puanlarında anlamlı bir farklılığa neden olmadığı bulgusu Dede ve Dursun (2008)'un ilköğretim II. kademe öğrencilerinin matematik kaygı düzeylerinin sınıf değişkenine göre değişmediği sonuçları ile örtüşmektedir.

Çalışmada kız öğrencilerin erkek öğrencilere, 8.sınıf öğrencilerinin 7.sınıf öğrencilerine göre benlik saygısı düzeyleri daha yüksektir. Ancak cinsiyet ve sınıf değişkenlerinin benlik saygısı puanlarında anlamlı bir farklılık oluşturmadığ 1 belirlenmiştir. Çuhadaroğlu (1985)'nun gençlerde benlik saygısına ilişkin yaptığ çalışmada kız ve erkek öğrenciler arasında fark bulunmadığı ancak kızların benlik algılarındaki sürekliliğin anlamlı ölçüde yüksek olduğunu belirlemiştir. Biçkur (2015) üniversite sınavına girecek öğrencilerin sınav kaygısı, benlik saygısı ve anne-baba tutumu arasındaki ilişkiyi incelediği çalışmasında kız ve erkek öğrencilerin benlik saygısı puan ortalamaları arasında fark olmadığını saptamıştır. Uyanık Balat ve Akman (2004) farklı 
sınıflara devam eden lise öğrencilerinin benlik saygısı puan ortalamaları arasında fark olmadığını belirlemişlerdir.

Üniversite mezunu anneye sahip olan öğrencilerin sınav kaygısı puan ortalamalarının, okur-yazar olmayan anneye sahip öğrencilerin ortalamalarından daha yüksektir. Hanımoğlu ve Yazgan İnanç (2011) çalışmalarında öğrencilerin anneden algılanan kabul/ilgi düzeyleri artıkça, sınav kaygısı toplam puanlarının düştüğünü; olumsuz mükemmeliyetçilik puanları arttıkça, sınav kaygısı toplam puanlarının yükseldiğini belirlemişlerdir. Özellikle bu sonuç üniversite mezunu annelerin mükemmeliyetçi olmaları öğrencilerin daha yoğun sınav kaygısı yaşamalarının sonucu olarak düşünülebilir. Üniversite mezunu babaya sahip olan öğrencilerin sınav kaygısı puan ortalamaları ise diğer grupta yer alan öğrencilerin puan ortalamalarından daha düşüktür. Ancak sınav kaygısı puan ortalamaları arasında anne - baba eğitim durumu değişkeninin anlamlı bir farklılık oluşturmadığ 1 saptanmıştır.

Benlik saygısı puanlarının anne-baba eğitim durumu değişkenine göre incelendiğinde, üniversite mezunu anneye sahip öğrencilerle, okur -yazar olmayan babaya sahip olan öğrencilerin düşük benlik saygıs1 düzeyine sahip oldukları belirlenmiş̧ir. Ancak analiz sonucunda benlik saygısı puan ortalamaları arasında annebaba eğitim durumunun anlamlı bir farklılık oluşturmadığı saptanmıştır. Kahriman (2005) yaptığı çalışmada, annenin eğitim durumu ile benlik saygısı puan ortalamaları arasındaki farkın istatistiksel olarak anlamlı olmadığını belirlemiştir. Yılmaz ve Ekinci'nin (2001) hemşirelik öğrencileri üzerinde yaptıkları araştırmada da, aile eğitim durumunun öğrencilerin benlik saygısını etkilemediğini saptamıșlardır. Biçkur (2015) üniversite sınavına girecek öğrencilerle yaptığı çalışmada, anne-baba eğitim durumunun benlik saygısı puan ortalamalarında farklılık yaratmadığını belirlemiştir. Bu sonuç ailelerin, öğrencilerin özgüvenlerini geliştirmesine katkıda bulunmaları, kısıtlama ve özgürlük arasında sağlıklı bir denge oluşturmaları, iletişimlerinin sağlkklı olması, ergen çocuklarını bir birey olarak kabul edip değer vermelerinin etkisinin ebeveynin eğitim durumundan etkilenmediği yorumunu getirmektedir.

Çalışmanın diğer bir sonucu da sınav kaygısı ile benlik saygısı puanları arasında negatif yönde anlamlı bir ilişki olduğudur. Hangi öğrencilerin akademik risk altında olabileceğinin göstergeleri arasında özellikle benlik saygısı ve sınav kaygısı değişkenleri önemli görülmektedir. Küçük (2010) müzik öğretmeni adaylarının sınav kaygısı ile benlik saygısı düzeyi arasında anlamlı bir ilișki saptamıștır. Hay, Ashman ve Van Kraayenoord (1998) yaptıkları araştırmada yüksek benlik saygısına sahip öğrencilerin daha az kaygı duyduklarını belirlemişlerdir. Kabalcı (2008) ilköğretim ikinci kademe öğrencilerinde sınav kaygısı, benlik saygısı ve akademik başarı ilişkisini incelemiş ve formal bir sınav veya değerlendirme durumunda yaşanan, bireyin gerçek performansını ortaya koymasını engelleyen, bilişsel, duyuşsal ve davranışsal özellikleri olan, bireyde gerginlik yaratan hoş olmayan bir durum olarak tanımlanan sınav kaygısı ile bireyin kendisini nasıl gördüğü olarak tanımlanan benlik saygısı arasındaki ilişkinin istatistiksel olarak anlamlı olduğunu saptamıştır. Sınav kaygısı yüksek olan bireylerin, kendilerine yönelik olumsuz düşünceler geliştirmesi, sınav kaygısı ile benlik saygısı kavramı arasındaki ilişkiyi ortaya koymaktadır. Bireyin olumsuz düşüncelere sahip olması benlik saygısını olumsuz etkileyerek sınav kaygısı düzeyinin artmasına neden olabilmektedir.

Günümüzde öğrenciler başarı elde etmek, sınavlardan istedikleri puanları alabilmek için çok yoğun çaba sarf etmektedirler. Sınav kaygısı, ailelerin beklentileri ve benlik saygısı gibi etmenler yüzünden hedefe ulaşmada zorluk yaşamaktadırlar. Günümüz mevcut sınav sisteminden dolayı öğrenciler birbirleri ile yarıştıkları için başarı seviyeleri düşmektedir. Bu durumu yaşayan öğrenciler öncelikle olumlu anne-baba tutumu ile daha sonra sınıf öğretmenleri ve okul rehberlik servisi ile desteklenmelidir. Çalışmanın sınırlılığı Kırıkkale ili sınırlı kalmıştır. Diğer sınıf düzeyleri ile daha çok öğrenciye ulaşılıp çalışma yapılabilir.

\section{KAYNAKÇA}

Aydın, U., \& Bulgan, G. (2017). Çocuklarda sınav kaygısı ölçeği'nin Türkçe uyarlaması: geçerlik ve güvenirlik çalışması. İlköğretim Online, 16(2): 887-899.

Bacanlı,F. \& Sürücü, M. (2006). İlköğretim 8. sınıf öğrencilerinin sınav kaygıları ve karar verme stilleri arasındaki ilişkilerin incelenmesi. Kuram ve Uygulamada Eğitim Yönetimi, Sayı 45, 7-35.

Başoğlu, S. T. (2007). Sinav kaygısı ile özgüven arasındaki ilişkinin erinlik döneminde incelenmesi. Yayınlanmamış yüksek lisans tezi, Maltepe Üniversitesi Sosyal Bilimler Enstitüsü, İstanbul. 
Biçkur, B.(2015). Üniversite sınavına girecek öğrencilerin sınav kaygısı, benlik saygısı ve anne-baba tutumu arasındaki ilişkinin incelenmesi. Yayınlanmamış yüksek lisans tezi, Üsküdar Üniversitesi Sosyal Bilimler Enstitüsü, İstanbul.

Brown, T. A. (2006). Confirmatory factor analysis for applied research. New York: Guilford.

Cassady, C. J., Johnson, E. R. (2002). Cognitive test anxiety and academic performance. Contemporary Educational Psychology. 27, 270-295.

Çelebi,B. (2007). İlköğretim II. Kademe Öğrencilerinin Korkuları: Akademik Başarıya Etkisi. Yayınlanmamış yüksek lisans tezi, Niğde Üniversitesi, Sosyal Bilimler Enstitüsü, Niğde.

Çuhadaroğlu, F. (1985). Gençlerde benlik saygısı ile ilgili bir araştırma. XXI. Ulusal Psikiyatr ve Nörolojik Bilimler Kongresi Bilimsel Çalı̧̧maları, Adana.

Çuhadaroğlu,F.(1986). Adolesanlarda benlik saygısı. Uzmanlık Tezi, Hacettepe Üniversitesi, Tıp Fakültesi, Ankara.

Dede,Y. \& Dursun,Ş. (2008). İlköğretim ikinci kademe öğrencilerinin matematik kaygı düzeylerinin incelenmesi . Uludağ Üniversitesi Ĕ̈itim Fakültesi Dergisi, XXI(2),295-312.

Di Maria, F.\& Di Nuovo, S. (1990). Gender differences in social and test anxiety. Personality and Individual Differences, 11, 525-530.

Duman, G. K. (2008). ‘ilköğretim 8. sınıf öğrencilerinin durumluk sürekli kaygı düzeyleri ile sınav kaygısı düzeyleri ve ana - baba tutumları arasındaki iliş̧inin incelenmesi', Yayınlanmamış yüksek lisans tezi, Dokuz Eylül Üniversitesi, Eğitim Bilimleri Enstitüsü, İzmir.

Dündar, S., Yapici, Ş., \& Topçu, B. (2008). Üniversite öğrencilerinin bazı kişilik özelliklerine göre sınav kaygısının incelenmesi. Gazi Eğitim Fakültesi Dergisi, 28(1):171-186.

Erözkan, A. (2011). Üniversite öğrencilerinin sınav kaygısı ve başa çıkma davranışları. Sosyal ve Beşeri Bilimler Araştırmaları Dergisi, 1(12): 13-38.

Hanımoğlu, E. \& İnanç Yazgan,B. (2011). Seviye belirleme sınavına girecek olan ilköğretim ikinci kademe öğrencilerinde sınav kaygısı, mükemmeliyetçilik ve anne-baba tutumu arasındaki ilişkinin incelenmesi. Ç.Ü. Sosyal Bilimler Enstitüsü Dergisi, 20,(1); 351-366

Hay, I., Ashman, A.F., \& Van Kraayenoord, C.E. (1998). Educational characteristics of students with high or low self-concept. Psychology in the Schools, 35(4): 391-400.

İnanç, B. Y. \& Yerlikaya, E. E. (2008). Kişilik kuramları. Ankara: Pegem Akademi.

Gülbahçe, A. \& Kartol, A. (2016). İlköğretim sekizinci sınıf öğrencilerinin karar verme stratejilerinin bazı değiş̧kenler açısından incelenmesi. Bayburt Eğitim Fakültesi Dergisi, 9(2), 132-143.

Kabalcı, T. (2008). Akademik başarının yordayıcısı olarak benlik saygısl, sinav kaygısı ve sosyo-demografik değişkenler. Yayınlanmamış yüksek lisans tezi, Hacettepe Üniversitesi Sosyal Bilimler Enstitüsü, Ankara.

Kahriman, İ. (2005). Karadeniz Teknik Üniversitesi Trabzon Sağlık Yüksekokulu öğrencilerinin benlik saygıları ve atılganlık düzeylerinin bazı değişkenler açısından incelenmesi. Cumhuriyet Üniversitesi Hemşirelik Yüksekokulu Dergisi, 9(1);24-32.

Karasar, N. (2008). Bilimsel Araştırma Yöntemi. Ankara: Nobel Yayınları.

Öner, N. (1989). Sinav kaygısı envanteri el kitabı. İstanbul: Yükseköğretimde rehberliği yayma vakfı Yayını No:1.

Pişkin, M. (2003). Özsayg1 geliştirme eğitimi. (ed. Y. Kuzgun) İlköğretimde Rehberlik: Ankara: Nobel Yayınları. 
Kayapınar,E.(2006). Ortaöğretim kurumları öğrenci seçme ve yerleştirme sınavı (OKS)'na hazırlanan ilköğretim 8. sınıf öğrencilerinin kaygı düzeylerinin incelenmesi (Afyonkarahisar ili örneği). Yayınlanmamış yüksek lisans tezi, Sosyal Bilimler Enstitüsü, Ankara.

Rasor, I. T. \& Rasor, R. A. (1998). Test anxiety and study behavior of community college students in relation to ethnicity, gender and age. (ED 415942).

Rosenberg, M. (1989). Society and The Adolescent Self-Image, Düzeltilmiş Baskı, Middletown, CT, Wesley an University Press.

Spielberger, C. (1972). Theory and Research in Anxiety. New York, Academic Press.

Uyanık Balat,G. \& Akman,B. (2004). Farklı sosyo-ekonomik düzeydeki lise öğrencilerinin benlik saygısı düzeylerinin incelenmesi. Firat Üniversitesi Sosyal Bilimler Dergisi Cilt: 14, Sayı: 2, Sayfa: 175-183.

Uysal, O. (2007). İlköğretim ikinci kademe öğrencilerinin matematik dersine yönelik problem çözme becerileri, kaygıları ve tutumları arasındaki ilişskilerin değerlendirilmesi. Yüksek Lisans Tezi, Dokuz Eylül Üniversitesi, İzmir.

Ünal, A. (2006). OKS (LGS)'ye hazırlanan ögrrencilerin sinav kayglları ile benlik saygı düzeyleri arasindaki iliş̧kinin incelenmesi. Yayınlanmamış yüksek lisans tezi, Gazi Üniversitesi Sosyal Bilimler Enstitüsü, Ankara.

Yılmaz, S. \& Ekinci, M. (2001). Hemşirelik Yüksekokulu öğrencilerinde benlik saygısı ve atılganlık düzeyi arasındaki ilişki, Atatürk Üniversitesi Hemşirelik Yüksekokulu Dergisi, 4(2).

Yörükoğlu, A. (2000). Çocuk Ruh Sağllğı. İstanbul: Özgür Yayınları.

Zeidner, ML. \& Schleyer, E. J. (1999). Test anxiety in intellectually gifted students'. Anxiety, Stress and Coping, $12 ; 163-190$.

\section{EXTENDED SUMMARY}

The purpose of this study is to examine the relationship between test anxiety and self-esteem in the case of 7th and 8th grade students and to establish whether certain variables (gender, grade, parental educational status) bring about a difference in the scores of test anxiety and self-esteem.

The study group consists of a total of 334 students, 163 female and 171 male, attending seventh and eighth grades. Of these students, 167 of them are seventh grade students and 167 of them eighth grade students.

Data pertaining to the study was collected through Personal Information Forms, which were prepared by the researchers for the purpose of obtaining demographic details regarding the secondary school students, Test Anxiety Inventory, which was originally developed by Spielberger (1972) and adapted to Turkish by Öner (1990), and Rosenberg Self-Esteem Scale that was developed by Morris Rosenberg with the aim of identifying the levels of self-esteem in the case of 7 th and 8th grade students.

As a result of the study, there seems to be a statistically significant relationship between test anxiety which is identified as an undesirable cognitive, affective and behavioral condition experienced in the event of a formal examination or assessment which prevents individual from realizing his/her true potential and ultimately causes stress for the individual- and self-esteem, which is described as how one sees himself/herself.

It was found that average test anxiety scores of the female students $(\bar{X}=41.80)$ were higher than that of the male students ( $\bar{X}=39.66$ ) and that the students' test anxiety scores differed significantly based on gender. In terms of grade variable, however, it was established that the average test anxiety scores of the 8th grade students $(\bar{X}=42.08)$ were higher than that of the 7 th grade students $(\bar{X}=40.40)$, and yet the t-test results revealed that the grades of the students did not make any statistically significant difference in their test anxiety scores ( $p>05)$. According to the Rosenberg Self-Esteem Scale scoring system, high scores indicate low levels of self-esteem, whereas low scores indicate high levels of self-esteem. It was established that the levels of self-esteem were higher in female students than in male students and in 8th grade students than in 7th grade students, and yet the 
analysis results showed that the variables of gender and grade did not bring about any statistically significant difference in self-esteem scores.

It seems that the average test anxiety scores of the students with university graduate mothers ( $\bar{X}=42.05)$ are higher than that of the students with illiterate mothers $(\bar{X}=39.13)$. The average test anxiety scores of those with university graduate fathers, on the other hand, appears to be lower than that of the other group of students. As a result of the analysis, the difference observed in the average test anxiety scores in terms of parental educational status was not found to be statistically significant. It was established that students with university graduate mothers ( $\bar{X}=1.44)$ and the students with illiterate fathers $(\bar{X}=1.27)$ had low levels of selfesteem. As a result of the analysis, it was established that the parental educational status did not make a statistically significant difference in the average self-esteem scores. As a result of the Pearson Product Moment Correlation analysis, which was conducted to identify to relationship between the scores of test anxiety and selfesteem, a statistically significant relationship was established between the said scores $(\mathrm{p}<.05)$.

Nowadays, students go to great lengths to get desirable scores in exams and achieve academic success. They are challenged by a number of factors such as test anxiety, parental expectations and self-esteem in achieving their goals. Due to the fact that the existing test system forces students into competing with each other, their levels of success are in decline. The students experiencing this situation should, first of all, be supported by a positive parental attitude and then by their class teachers and school counseling services. This study is exclusively limited to the province of Kırıkkale. The scope of the study can be extended to other grade levels to include more students. 